\title{
The Role of Post-Translational Modifications on Prion-Like Aggregation and Liquid-Phase Separation of FUS
}

\author{
Shannon N. Rhoads, Zachary T. Monahan, Debra S. Yee and Frank P. Shewmaker* \\ Department of Pharmacology and Molecular Therapeutics, Uniformed Services University of the Health \\ Sciences, Bethesda, MD 20814, USA; shannon.rhoads.ctr@usuhs.edu (S.N.R.); \\ zachary.monahan@usuhs.edu (Z.T.M.); debra.yee.ctr@usuhs.edu (D.S.Y.) \\ * Correspondence: fshewmaker@usuhs.edu; Tel.: +1-301-295-3527
}

Received: 30 January 2018; Accepted: 7 March 2018; Published: 16 March 2018

\begin{abstract}
Subcellular mislocalization and aggregation of the human FUS protein occurs in neurons of patients with subtypes of amyotrophic lateral sclerosis and frontotemporal dementia. FUS is one of several RNA-binding proteins that can functionally self-associate into distinct liquid-phase droplet structures. It is postulated that aberrant interactions within the dense phase-separated state can potentiate FUS's transition into solid prion-like aggregates that cause disease. FUS is post-translationally modified at numerous positions, which affect both its localization and aggregation propensity. These modifications may influence FUS-linked pathology and serve as therapeutic targets.
\end{abstract}

Keywords: FUS; ALS; FTLD; prion; amyloid; LLPS

\section{The Link between FUS and Neurodegenerative Disease}

FUS (fused in sarcoma) gets its name from forming oncogenic fusion proteins with specific transcription factors following chromosomal rearrangements [1]. Such rearrangement is common in liposarcomas, thus FUS also goes by the name TLS (translocated in liposarcoma). Since 2009, FUS has received more attention for its connection to neurodegenerative disease after missense mutations were discovered to cause a small percentage of cases of amyotrophic lateral sclerosis (ALS-FUS) [2,3]. In the motor neurons of these patients, the normally nuclear FUS protein was found in cytoplasmic proteinaceous inclusions. Since then, non-mutant FUS has been identified in cytoplasmic inclusions in cortical neurons of a subset of patients with frontotemporal dementia (FTD; the neuropathological diagnosis is termed frontotemporal lobar degeneration (FTLD-FUS)) [4]. Both ALS and FTD are incurable and their clinical and pathological overlap suggests that they are part of a disease continuum.

Mutations in FUS are autosomal dominant causes of familial ALS. Most mutations alter the C-terminal nuclear localization signal, resulting in excess cytoplasmic FUS that can form inclusions with gain-of-function toxicity [5]. Whether ALS-FUS or FTLD-FUS, it is the accumulation of FUS into cytoplasmic aggregates that appears to cause neuronal loss. The clinical presentation likely depends on the specific type of neurons that are affected. Biophysical and histological analysis suggest that FUS cytoplasmic aggregation may spread across anatomical networks through a prion-like mechanism [6]. Therefore, future drugs may target FUS's ability to cytoplasmically localize and/or form proteinaceous aggregates. Extensive post-translational methylation and phosphorylation of FUS have been shown to influence localization and aggregation, respectively. Here we review the post-translational modifications (PTMs) of FUS in the context of how they affect function, self-association and pathology. 


\section{FUS Structure and Function}

FUS is a ubiquitously expressed, predominantly nuclear, metazoan protein. Many different functions-primarily involving RNA metabolism and processing-have been ascribed to FUS. Its domain architecture is presented in Figure 1. The amino-terminal prion-like domain (PrLD) has garnered much attention because its composition is similar to the domains found in yeast proteins that form self-propagating amyloid fibers (described below). FUS also contains multiple arginine/glycine-rich regions (RGG; named for a repeated arginine-glycine-glycine motif), an RNA-recognition motif (RRM), zinc finger $(\mathrm{ZnF})$, and nuclear export (NES) and localization sequences (NLS).

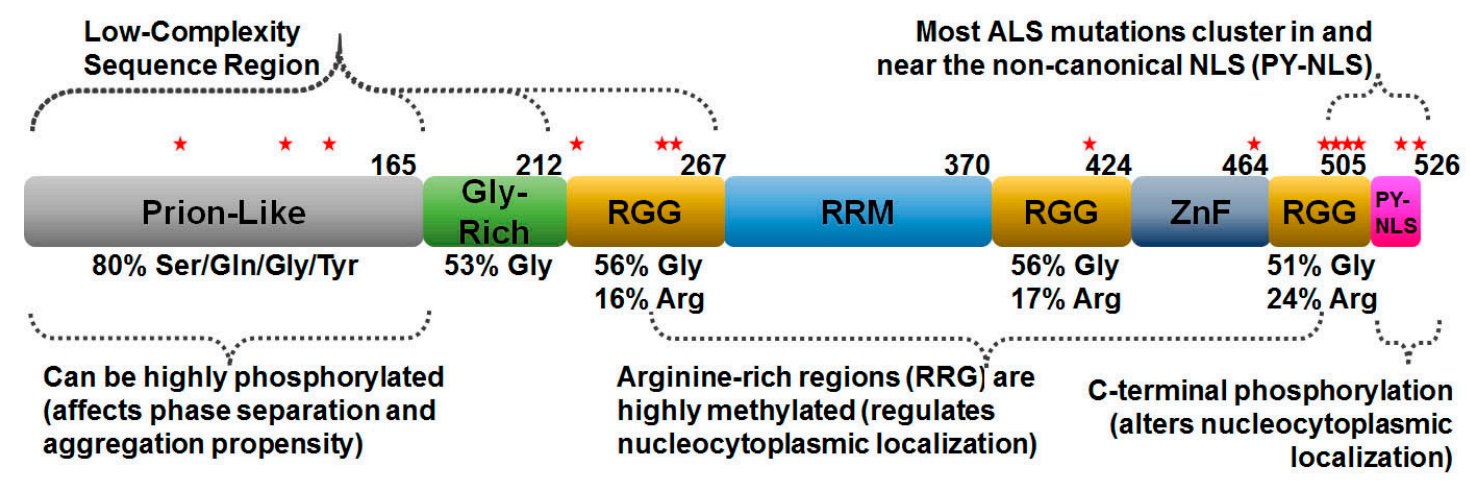

Figure 1. Schematic of human FUS domain organization. Approximately the first half of FUS has little sequence complexity and consists mostly of a few different amino acids. This region is sometimes called the low-complexity domain. The prion-like domain (PrLD) shares sequence composition with domains in yeast proteins that form self-replicating amyloid structures (i.e., prions). FUS's PrLD is highly phosphorylated following certain stresses. The RGG domains contain the triplet repeat motif of arginine-glycine-glycine, which are extensively methylated. FUS also contains an RNA-recognition motif (RRM), a zinc-finger domain (ZnF), and a proline-tyrosine nuclear localization signal (PY-NLS). The red stars indicate ALS mutation sites that are also post-translationally modified (see Table 1).

The physiological functions of FUS are not fully characterized and remain an area of active investigation. Early work with FUS-knockout organisms suggested a critical developmental function, but specific molecular activities remained ambiguous [7-10]. One of the most challenging aspects of understanding FUS physiology is its apparent diversity of functions. Broadly, these functions can be divided into three categories: DNA damage response, RNA metabolism, and the cellular stress response [11-17]. That it adopts such diverse roles suggests an accessory role for FUS in each of these categories; were it a central player in any category, we may expect its physiological repertoire to be more limited to that function.

In the DNA damage response (DDR), FUS has been shown to localize at sites of laser-induced DNA damage [18,19], to interact with HDAC1-mediated DNA repair pathways [20], and to interact with poly-ADP ribose, a by-product of DNA damage [18,19]. Disease-associated mutations limit FUS's participation in DDR [21], perhaps due to enhanced cytoplasmic mislocalization [22]. Moreover, studies have now also shown post-translational modification of FUS to be coincident with DNA damage $[18,23]$. This suggests that PTMs are a possible modifier of its function in these pathways. Most telling, studies have documented increased evidence of DNA damage in cells expressing mutant FUS [20]. Therefore, while its precise function is still unclear, the function of FUS in the DDR is clearly consequential.

The most well-established roles for FUS in RNA metabolism involve three critical functions: mRNA transport and translation [13,14], gene splicing [11,12,20,24], and gene expression [17,25,26]. Each of these functions involves association of FUS with other players, including molecular motor proteins such as Myo5A and KIF5B for mRNA transport $[8,27,28]$, and U11 snRNP for splicing 
functions [20,29]. Additionally, FUS has been shown to interact with transcriptional regulators, RNA pol II, and regulatory regions of DNA, thus mediating mRNA synthesis $[8,12,17,25,26]$. Disease-associated mutations in FUS have been shown to impair its role in many of these functions [30,31].

The response of FUS to general cellular stress involves association with ribonucleoprotein (RNP) bodies/granules-which are transient regulatory structures. Examples include stress granules (SGs) and processing bodies (P-bodies), which are sites of altered RNA metabolism, in response to specific stressors. The formation of FUS-positive SGs and P-bodies has been observed in the face of osmotic stress, as well as heat-shock [8,16,32]. FUS's roles in RNA processing functions may explain its association with these structures [16].

The three general functions for FUS listed above are disparate from one another. Nevertheless, one unifying principle is that FUS must have a mode of protein-protein interaction that facilitates localization at different subcellular sites that perform different functions. This ability to localize at DNA lesions, with other RNA processing proteins at mRNAs, and at sites of SG formation may explain why FUS has retained such a robust capacity for self-association and liquid-like phase separation (discussed below).

Table 1. Post-translational modifications (PTMs) of FUS.

\begin{tabular}{|c|c|c|c|}
\hline Amino Acid & Modification & Evidence & Ref. \\
\hline A2 & A & $\mathrm{MS}^{2}$ & {$[33,34]$} \\
\hline S3 & $\mathrm{P}$ & $\mathrm{MS}^{2}$ & [33] \\
\hline T7 & $\mathrm{P}$ & $\mathrm{MS}^{1}, \mathrm{MS}^{2}, \mathrm{NMR}$ & {$[33,35,36]$} \\
\hline T11 & $\mathrm{P}$ & $\mathrm{MS}^{1}, \mathrm{NMR}$ & {$[35,36]$} \\
\hline T19 & $\mathrm{O}-\mathrm{g} ; \mathrm{P}$ & $\mathrm{MS}^{1}, \mathrm{NMR}$ & {$[35-37]$} \\
\hline S26 & $\mathrm{P}$ & $\mathrm{MS}^{1}, \mathrm{MS}^{2}, \mathrm{NMR}, \mathrm{SEQ}, \mathrm{AB}$ & {$[23,33,36,38]$} \\
\hline S30 & $\mathrm{P}$ & $\mathrm{MS}^{1}, \mathrm{MS}^{2}, \mathrm{NMR}, \widetilde{\mathrm{AB}}$ & {$[33,35,36]$} \\
\hline S37 & $\mathrm{P}$ & $\mathrm{MS}^{2}$ & {$[33,36]$} \\
\hline S42 & $\mathrm{P}$ & $\mathrm{MS}^{1}, \mathrm{MS}^{2}, \mathrm{NMR}, \mathrm{SEQ}, \mathrm{AB}$ & {$[23,33,35,36,38]$} \\
\hline S54 & $\mathrm{P}$ & MS $^{1}$ & [35] \\
\hline S57 & $\mathrm{P}$ & $\mathrm{MS}^{2}$ & [33] \\
\hline S61 & $\mathrm{P}$ & $\mathrm{MS}^{1}, \mathrm{MS}^{2}, \mathrm{NMR}, \mathrm{SEQ}$ & {$[23,35,36,38]$} \\
\hline T68 & $\mathrm{P}$ & NMR & [36] \\
\hline T71 & $\mathrm{P}$ & $\mathrm{MS}^{2}$ & [36] \\
\hline S77 & $\mathrm{P}$ & $\mathrm{MS}^{2}$ & {$[33,36]$} \\
\hline T78 & $\mathrm{P}$ & $\mathrm{MS}^{2}$ & {$[33,36]$} \\
\hline S84 & $\mathrm{P}$ & $\mathrm{MS}^{1}, \mathrm{NMR}, \mathrm{SEQ}$ & {$[23,35,36,38]$} \\
\hline S86 & $\mathrm{P}$ & $\mathrm{MS}^{2}$ & [33] \\
\hline S87 & $\mathrm{P}$ & $\mathrm{MS}^{1}, \mathrm{MS}^{2}, \mathrm{NMR}$ & {$[33,35,36]$} \\
\hline S95 & $\mathrm{P}$ & $\mathrm{MS}^{2}$ & [33] \\
\hline S96 & $\mathrm{P}$ & $\mathrm{MS}^{2}$ & {$[33,36]$} \\
\hline S108 & $\mathrm{P}$ & $\mathrm{MS}^{2}$ & [39] \\
\hline T109 & $\mathrm{P}$ & $\mathrm{MS}^{2}$ & {$[33,36]$} \\
\hline S110 & $\mathrm{P}$ & $\mathrm{MS}^{2}$ & {$[33,36]$} \\
\hline S112 & $\mathrm{P}$ & $\mathrm{MS}^{1}, \mathrm{MS}^{2}$ & {$[33,35]$} \\
\hline S115 & $\mathrm{P}$ & $\mathrm{MS}^{2}$ & [33] \\
\hline S117 & $\mathrm{P}$ & $\mathrm{MS}^{1}, \mathrm{MS}^{2}, \mathrm{NMR}$ & {$[33,35,36]$} \\
\hline S127 & $\mathrm{P}$ & $\mathrm{MS}^{2}$ & [36] \\
\hline S129 & $\mathrm{P}$ & $\mathrm{MS}^{2}$ & [33] \\
\hline S131 & $\mathrm{P}$ & $\mathrm{MS}^{1}, \mathrm{MS}^{2}, \mathrm{SEQ}$ & {$[23,35,39]$} \\
\hline S135 & $\mathrm{P}$ & $\mathrm{MS}^{2}$ & [36] \\
\hline S142 & $\mathrm{P}$ & MS $^{1}$ & [35] \\
\hline S148 & $\mathrm{P}$ & $\mathrm{MS}^{2}$ & [36] \\
\hline R213 & $\mathrm{M}_{1}$ & $\mathrm{MS}^{2}$ & [40] \\
\hline R216 & $\mathrm{M}_{1}, \mathrm{M}_{2}$ & $\mathrm{MS}^{2}, \mathrm{AB}$ & {$[17,40-48]$} \\
\hline
\end{tabular}


Table 1. Cont.

\begin{tabular}{|c|c|c|c|}
\hline Amino Acid & Modification & Evidence & Ref. \\
\hline R218 & $\mathrm{M}_{1}, \mathrm{M}_{2}$ & $\mathrm{MS}^{2}, \mathrm{AB}$ & {$[17,40-48]$} \\
\hline $\mathrm{S} 221$ & $\mathrm{P}$ & $\mathrm{MS}^{2}$ & {$[39,43,49,50]$} \\
\hline Y232 & $\mathrm{P}$ & $\mathrm{MS}^{2}$ & [43] \\
\hline R234 & $\mathrm{M}_{1}$ & $\mathrm{MS}^{2}$ & [41] \\
\hline $\mathrm{R} 242$ & $\mathrm{M}_{1}, \mathrm{M}_{2}$ & $\mathrm{MS}^{2}$ & {$[17,40-43,51]$} \\
\hline R244 & $\mathrm{M}_{1}, \mathrm{M}_{2}$ & $\mathrm{MS}^{2}$ & {$[41,42,51]$} \\
\hline $\mathrm{R} 248$ & $\mathrm{M}_{1}, \mathrm{M}_{2}$ & $\mathrm{MS}^{2}$ & {$[41,42,51]$} \\
\hline R251 & $\mathrm{M}_{2}$ & $\mathrm{MS}^{2}$ & {$[42,51]$} \\
\hline $\mathrm{S} 256^{*}$ & $\mathrm{P}$ & MUT & {$[52]$} \\
\hline R259 & $\mathrm{M}_{1}, \mathrm{M}_{2}$ & $\mathrm{MS}^{2}$ & {$[40-43,51]$} \\
\hline K264 & U & $\mathrm{MS}^{2}$ & [53] \\
\hline R269 & $\mathrm{M}_{1}$ & $\mathrm{MS}^{2}$ & [41] \\
\hline S273 & $\mathrm{P}$ & $\mathrm{MS}^{2}$ & [43] \\
\hline S277 & $\mathrm{P}$ & $\mathrm{MS}^{2}$ & {$[43,54-59]$} \\
\hline $\mathrm{T} 286$ & $\mathrm{P}$ & $\mathrm{MS}^{2}$ & [58-60] \\
\hline Y304 & $\mathrm{P}$ & $\mathrm{BP}^{1}, \mathrm{BP}^{2}$ & {$[61,62]$} \\
\hline K316 & $\mathrm{U}$ & $\mathrm{MS}^{2}$ & {$[43,63-65]$} \\
\hline $\mathrm{T} 317$ & $\mathrm{P}$ & $\mathrm{MS}^{2}$ & [66] \\
\hline Y325 & $\mathrm{P}$ & $\mathrm{MS}^{2}, \mathrm{BP}^{1}, \mathrm{BP}^{2}$ & {$[43,61,62,66,67]$} \\
\hline T326 & $\mathrm{P}$ & $\mathrm{MS}^{2}$ & {$[66,67]$} \\
\hline K332 & A & $\mathrm{MS}^{2}$ & {$[53]$} \\
\hline K334 & $\mathrm{U}$ & $\mathrm{MS}^{2}$ & [53] \\
\hline S340 & $\mathrm{P}$ & $\mathrm{MS}^{2}$ & {$[49,54,56,68,69]$} \\
\hline S346 & $\mathrm{P}$ & $\mathrm{MS}^{2}$ & {$[54,56,58,67]$} \\
\hline K348 & $\mathrm{U}$ & $\mathrm{MS}^{2}$ & [64] \\
\hline K357 & $\mathrm{A} ; \mathrm{U}$ & $\mathrm{MS}^{2}$ & {$[43,53]$} \\
\hline S360 & $\mathrm{P}$ & $\mathrm{MS}^{2}$ & [54] \\
\hline K365 & $\mathrm{M}_{1} ; \mathrm{U}$ & $\mathrm{MS}^{2}$ & {$[63,65,70]$} \\
\hline R371 & $\mathrm{M}_{1}$ & $\mathrm{MS}^{2}$ & {$[40-42]$} \\
\hline R377 & $\mathrm{M}_{2}$ & $\mathrm{MS}^{2}$ & [51] \\
\hline R383 & $\mathrm{M}_{1}, \mathrm{M}_{2}$ & $\mathrm{MS}^{2}$ & {$[41,51]$} \\
\hline R386 & $\mathrm{M}_{2}$ & $\mathrm{MS}^{2}$ & [51] \\
\hline R388 & $\mathrm{M}_{2}$ & $\mathrm{MS}^{2}$ & [51] \\
\hline R394 & $\mathrm{M}_{1}, \mathrm{M}_{2}$ & $\mathrm{MS}^{2}$ & {$[17,40,41,43,44,51]$} \\
\hline Y397 & $\mathrm{P}$ & $\mathrm{MS}^{2}$ & [71] \\
\hline R407 & $\mathrm{M}_{1}, \mathrm{M}_{2}$ & $\mathrm{MS}^{2}$ & {$[40,41,43,51]$} \\
\hline S439 & $\mathrm{P}$ & $\mathrm{MS}^{2}$ & [54] \\
\hline K448 & $\mathrm{U}$ & $\mathrm{MS}^{2}$ & [53] \\
\hline S462 & $\mathrm{P}$ & $\mathrm{MS}^{2}$ & {$[43,53,54,72,73]$} \\
\hline Y468 & $\mathrm{P}$ & $\mathrm{MS}^{2}$ & {$[43,67,74,75]$} \\
\hline $\mathrm{R} 472$ & $\mathrm{M}_{1}$ & $\mathrm{MS}^{2}$ & [44] \\
\hline $\mathrm{R} 473$ & $\mathrm{M}_{1}, \mathrm{M}_{2}$ & $\mathrm{MS}^{2}$ & {$[40,44,51]$} \\
\hline R476 & $\mathrm{M}_{1}, \mathrm{M}_{2}$ & MS $^{2}$ & {$[41,44,51]$} \\
\hline R481 & $\mathrm{M}_{1}, \mathrm{M}_{2}$ & $\mathrm{MS}^{2}$ & {$[41,43,51]$} \\
\hline R485 & $\mathrm{M}_{1}, \mathrm{M}_{2}$ & $\mathrm{MS}^{2}$ & {$[41,43,51]$} \\
\hline R487 & $\mathrm{M}_{1}, \mathrm{M}_{2}$ & $\mathrm{MS}^{2}$ & {$[41,51]$} \\
\hline R491 & $\mathrm{M}_{2}$ & $\mathrm{MS}^{2}$ & {$[46,51]$} \\
\hline R495 & $\mathrm{M}_{1}, \mathrm{M}_{2}$ & $\mathrm{MS}^{2}$ & {$[40,41,46,51]$} \\
\hline R498 & $\mathrm{M}_{2}$ & $\mathrm{MS}^{2}$ & {$[46,51]$} \\
\hline R503 & $\mathrm{M}_{1}, \mathrm{M}_{2}$ & $\mathrm{MS}^{2}$ & {$[40-44,46,51]$} \\
\hline R514 & $\mathrm{M}_{1}$ & $\mathrm{MS}^{2}$ & [40-42] \\
\hline Y526 & $\mathrm{P}$ & $\mathrm{AB}$ & [76] \\
\hline
\end{tabular}

Acetylation (A); GalNAc O-glycosylation (O-g); Monomethylation ( $\left.\mathrm{M}_{1}\right)$; Dimethylation $\left(\mathrm{M}_{2}\right)$; Phosphorylation $(\mathrm{P})$; Ubiquitination $(\mathrm{U})$. Mass spectrometry of recombinant protein $\left(\mathrm{MS}^{1}\right)$; mass spectrometry of cellular protein $\left(\mathrm{MS}^{2}\right)$; NMR of recombinant protein (NMR); protein sequencing (SEQ); bioinformatic prediction using Phospho Motif Finder $\left(\mathrm{BP}^{1}\right)$; bioinformatic prediction using NetPhos $3.1\left(\mathrm{BP}^{2}\right)$; ${ }^{*} \mathrm{FUS}$ isoform 2; antibody specific to PTM (AB); site-specific mutations (MUT); site of post translational modification and an ALS-associated mutation (grey background). Many additional sites are predicted in silico, but lack experimental corroboration. 


\subsection{FUS Can Undergo Liquid-Liquid Phase Separation}

Some biochemical reactions are spatially and temporally localized into discrete subcellular microenvironments that lack separating membranes. This can be achieved through liquid-liquid phase separation (LLPS), a process by which macromolecules separate from the bulk solvent into a distinct liquid phase [77]. These droplet-like microenvironments flow and fuse like liquids and tend to adopt spherical shapes [78,79]. They can assemble and disassemble in seconds, providing cells with the ability to respond to signals rapidly and specifically. Types of phase-separated structures include nucleoli [80], P-bodies [81], SGs [82], Cajal bodies [83], and sites of DNA damage [84]. Human FUS is hypothesized to undergo LLPS during inclusion in RNP bodies, mediating one of its many normal cellular functions discussed above.

Common features among proteins capable of undergoing LLPS include: long intrinsically disordered domains; domains with repeated motifs; and modular molecular-interaction domains (e.g., RNA-recognition motifs (RRMs)) [77,85]. Long intrinsically disordered domains generally have low sequence complexity and form complex structural ensembles that do not hydrophobically collapse. These domains and repeated sequence motifs appear to support the network of dynamic interactions enabling a phase-separated state without incurring a strong entropic penalty. FUS's amino-terminal PrLD is intrinsically disordered, contains multiple repeats of a S/GYS/G motif and is critical to FUS's condensation into a droplet state [12]. The repeat motif has the potential to be dramatically altered through tyrosine and serine phosphorylation. Electrostatic interactions between macromolecules are a known driving force for many systems that undergo LLPS [86], thus adding numerous negatively charged phosphates to the PrLD repeats is theoretically a means to regulate FUS's LLPS within cells (discussed further below) [87].

FUS's RRM is also likely involved in cellular LLPS. In vitro, recombinant FUS's phase separation is enhanced by the addition of RNA [12]. For many RNA-binding proteins that undergo LLPS, the addition of RNA generally decreases the saturation concentration for phase separation [77]. For example, the interaction between RNA and the RRM domains of hnRNPA1-a protein with many similarities to FUS-lowers the critical concentration for phase separation [82]. This may result from RNA's capacity for multivalent binding with numerous RRM domains enabling a network of interactions in the phase-separated state. PTMs that alter RRM binding would thus be a means to regulate LLPS. A recent bioinformatic study found that human RRM domains are among the most heavily modified domains in the proteome [88]. Interestingly, tyrosines within RNA-binding sites are commonly phosphorylated. Tyrosines 304 and 325 in the FUS RRM are both predicted phosphorylation sites in silico, and by mass spectrometry (Table 1), suggesting that FUS RRM-RNA interactions that mediate LLPS may be under the control of tyrosine kinases. The RRM and PrLD domains have received the most focus, but other domains and their PTMs may also contribute to LLPS. For example, removal of FUS's RRM is not sufficient to completely abrogate its RNA binding, so PTMs of other domains could also influence multivalent RNA interactions in the phase-separated state [14].

\subsection{FUS Can Form Prion-Like Solid Aggregates}

A distinguishing characteristic of most neurodegenerative diseases is that a single disease-linked protein aggregates in specific neuronal cells or tissue. In ALS, this happens in motor neurons; the specific pathological protein may be FUS, TDP-43, SOD1 or one of several other proteins [89]. Patient pathology follows not from aggregation occurring in an isolated cell, but through entire neural networks [6]. This pattern of pathology suggests propagation through physical contact, much like prion protein $(\operatorname{PrP})$, whose pathological conformation spreads through tissue in the fatal transmissible spongiform encephalopathies. Importantly, the misfolded form of PrP is itself toxic and serves as a template for other PrP molecules to convert into the pathological form [90]. Similarly, the aggregated form of FUS demonstrates gain-of-function toxicity in multiple cell and animal models [5,91-93]. ALS-linked FUS mutations have been shown to increase FUS's propensity to form solid aggregates $[84,94])$. 
A structural mechanism at the molecular level must underlie the faithful, yet catastrophic, propagation of specific protein aggregates. The single most unifying molecular model for misfolded protein propagation is amyloid, which is a filamentous protein homopolymer, with a high degree of structural order at the atomic level (i.e., amyloid is folded, albeit misfolded, but not structurally disorganized). Many different types of proteins can form amyloid, but much like a one-dimensional crystal, any specific amyloid filament is composed of repeated protein units of identical (or near identical) amino acid sequence. Protein backbones are aligned perpendicularly to the amyloid fiber axis in a configuration called "cross- $\beta$ ". The most common amyloid architecture has each polypeptide aligned in-register with the next polypeptide forming parallel $\beta$ sheets that run the length of the fiber axis. All yeast prion domains - from which FUS's amino-terminal domain gets its name-form parallel in-register amyloid in their infectious forms [95].

An amyloid configuration, based on parallel in-register $\beta$ sheets, depends on each amino acid lying adjacent to its exact counterpart in the next polypeptide. Introducing repulsive charged groups or other PTMs is structurally disruptive to this crystal-like arrangement. It is for this reason that PTMs, specifically within an amyloid-forming domain, may play an important role in disrupting FUS's pathological aggregation. Using solid-state NMR, Murray and coworkers identified a core region of FUS's PrLD (amino acids 39-95) that forms amyloid with parallel in-register $\beta$ sheet structure [35]. Importantly, this region overlaps with multiple putative sites of phosphorylation (Table 1) [33]; this is predicted to have strong influence on FUS's capacity to form solid aggregates (discussed below).

While FUS is demonstrably prone to aggregation [91,96], the architecture of its aggregate in diseased neurons is undetermined. When stained with thioflavin T dye, pathological FUS-positive inclusions do not yield a strong fluorescence like most amyloid-forming proteins [91]. However, this may be a peculiarity unique to FUS aggregates given that the PrLD of FUS unambiguously forms amyloid, while still exhibiting weak fluorescence responses to thioflavin $\mathrm{T}$ ([35] and unpublished observations). In summary, the most parsimonious explanation for FUS pathology is that it is based on prion-like, self-propagating, toxic aggregates for these reasons: FUS is autosomal dominant and neuronal cytoplasmic inclusions have gain-of-function toxicity; FUS inclusions follow distinct anatomical pathways in FUS-linked FTLD; FUS's PrLD forms archetypical amyloid providing a structural mechanism for self-propagation.

\subsection{FUS-Linked Disease May Result from an Irreversible Liquid-to-Solid State Transition}

Regardless of the atomic arrangement of FUS within neuronal inclusions, the phase-separated state has been implicated in potentiating the conversion into the solid-like pathological form [84]. Specifically, the high concentration of FUS in RNP bodies could stochastically facilitate an irreversible liquid-to-solid phase transition, especially under conditions involving mutant FUS and/or persistent RNP granules [97]. This hypothesis partly stems from the observation that many RNP body-associated proteins with prion-like domains are found in solid inclusions in neurodegenerative diseases [98], and from observations that prion-like domains appear to facilitate both phase separation and solid aggregate formation [82].

In vitro, FUS maintains a broad dynamic structural ensemble within liquid droplets; transient weak interactions, not solid-state interactions, facilitate phase separation [12]. However, if FUS droplets are subjected to multiple rounds of melting and re-separating, eventually they lose their pliability and resist melting [99]. These intractable droplets may form a 'glassy solid' in which liquid-like unstructured conformations become relatively locked [77], or they may form a 'hydrogel' composed of structured amyloid polymers [35]. Additionally, dense solid aggregates have been observed projecting from "locked" droplets, suggesting that interactions within the droplet state give rise to a solid-state conformation [84]. Disease-associated mutations that increase cytoplasmic localization of FUS can subsequently lead it to have more persistent association with cytoplasmic RNP bodies [100]. Also, mutant FUS is more prone to form a "locked" droplet state [99]. Thus, any PTM that affects FUS's phase separation or inclusion in RNP bodies may likewise affect FUS's potential to form pathological 
aggregates (discussed below). However, the fidelity with which these in vitro observations translate to FUS behavior in vivo is unclear.

\section{Post-Translational Modification of FUS}

PTMs have been suspected as critical mediators for pathological protein aggregation for years, especially in the context of neurodegenerative disease. For example, hyperphosphorylation of tau is widely suspected to be important in the pathogenesis of tauopathies, possibly by favoring the dissociation of tau from microtubules and thus favoring self-association and pathological aggregation [101]. However, others hypothesize that hyperphosphorylation disfavors tau aggregation, and thus may act as a protective mechanism $[102,103]$. Similarly opposing models for the role of phosphorylation in regulating protein self-assembly have emerged for other pathogenic proteins, such as alpha synuclein [104,105], TDP-43 [106,107], and FUS (described below). Thus, the precise roles of PTMs in facilitating pathology are not known. Likewise, the roles of PTMs in FUS pathology remain unresolved, despite observations that FUS undergoes extensive and complicated modification. Many of the sites that are modified are also known ALS mutation sites (Table 1, gray highlights). The most studied PTMs of FUS are serine/threonine phosphorylation and arginine methylation (Table 1).

\subsection{FUS Phosphorylation}

Prion-like amino acid sequences, being enriched in the residues serine, threonine, glutamine, asparagine, and tyrosine, have a high potential for phosphorylation. Not surprisingly, FUS phosphorylation has been extensively demonstrated in FUS's PrLD (Figure 1), as well as other domains (Table 1). Among the earliest work, FUS proteolysis was shown to be regulated by Ser-256 phosphorylation in its first RGG domain [52] (Figure 1). Later, more abundant phosphorylation was observed within the PrLD, described above as the mediator of FUS self-assembly and phase separation. Several studies have detected phosphorylation within this region using mass spectrometry, producing 32 putative sites at either serine or threonine residues (Table 1). No tyrosine phosphorylation in the PrLD has been detected in this manner-possibly due to technical challenges-despite being abundant in the repeated S/GYS/G motifs. Though threonine is not part of the repeated motif, multiple phospho-threonines have been identified.

Of the identified candidate phosphorylation sites in the PrLD, the first to be confirmed in mammalian cells by alternative methods was serine 42 using a site-specific antibody [23]. The responsible kinase was proposed to be ATM (ataxia-telangiectasia mutated ser/thr kinase). Gardiner and colleagues suggested that phosphorylation modulated the response of FUS to DNA damage but did not describe the specific role of phosphorylated FUS. Later, Deng and colleagues examined the effects of phosphorylation on FUS [18]. They characterized FUS phosphorylation in the PrLD and determined that it follows DNA-damage. They concluded that phosphorylation is mediated by DNA-PK at S/TQ motifs in the PrLD, and hypothesized that this could facilitate FUS cytoplasmic localization. Broadly, these findings were consistent with the results of two independent groups who demonstrated that FUS accumulation follows DNA damage at the site of lesions, and its assembly there is dependent on its PrLD [15,21,108]. Importantly, accumulation at lesion sites was not dependent on phosphorylation. Taken together, a model emerged wherein FUS phosphorylation mediated its subcellular localization immediately following its intranuclear role in the DNA damage response. Understanding the precise consequences of phosphorylation is critical given that cytoplasmic accumulation is considered one of the potentiators of disease.

In our recent findings, DNA-PK-dependent phosphorylation appeared to decrease the aggregation propensity of FUS [36]. Assays using yeast, human cell lines, and recombinant proteins established that both phase separation and toxic FUS aggregation are retarded by phosphorylation and/or phosphomimetic substitution in the $\operatorname{PrLD}[35,36]$. Both phosphorylation and its mimetic quantitatively reduce the prion-like nature of the PrLD by introducing electrostatic charges [36], thus offering an 
explanation for how these modifications reduce the propensity of the FUS PrLD to adopt the archetypal amyloid conformation and form cytoplasmic inclusions [35,109].

Separately, Lin and colleagues exploited a phase-separating in vitro model composed of poly-Src homology 3 (SH3) domain protein and poly-proline-rich-motif ligand to establish the effects of phosphorylation on phase separation [110]. When the FUS PrLD was fused to SH3, the system phase separated at lower concentration. Treating the system with DNA-PK to phosphorylate FUS PrLD eliminated the phase-separated droplets. All of these recent efforts are consistent with earlier work demonstrating that FUS PrLD retention within a hydrogel is disrupted by DNA-PK-dependent phosphorylation [38], but offer revelations for exactly how phosphorylation may regulate PrLD self-association [35], as well the consequences of phosphorylation on pathological aggregation, cytotoxicity, and physiological phase separation [36,110].

These results are also consistent with a broader biophysical phenomenon which is now emerging regarding the relationship of phosphorylation and protein-self association into phase-separated states. In a recent model system using cationic peptides and RNA, phosphorylation dramatically suppressed molecular condensation. Introduction of a single phosphoserine was sufficient to generate this effect [86]. The complex and extensive phosphorylation of FUS's PrLD suggests that phosphorylation is capable of regulating FUS's inclusion into RNP bodies. However, regulation of phase separation may not be limited to PrLD phosphorylation. Recent work showed that phosphorylation of S48 in TDP-43, distant from its own prion-like domain, altered phase separation in a recombinant protein system [111].

While critical to our understanding of FUS-linked pathology, the direct consequences of PrLD phosphorylation on FUS self-assembly does not address the finding previously suggested by Deng and colleagues. They suggested that phosphorylation played a role in mediating sub-cellular localization. We recently characterized conditions in which FUS PrLD phosphorylation is induced in human cells [33]. Phosphorylation at DNA-PK consensus sites-which were confirmed by antibodies specific to phosphoserines 26 and 30-did not directly alter subcellular localization of FUS. We additionally found that phosphorylation within the PrLD is extensive under some conditions, but occurs at lower frequencies under others, suggesting that differential phosphorylation may result in finer regulation of FUS activity.

While N-terminal phosphorylation seems to mediate self-association and not localization, C-terminal phosphorylation within the NLS (Figure 1) has been reported to disrupt the binding of nuclear import machinery, resulting in a higher cytoplasmic concentration of FUS [76,112]. One study found that the final amino acid, tyrosine 526, is phosphorylated by a Src family kinase [76]. Phosphorylation at this point decreased the binding affinity between FUS and transportin-1 (also known as Karyopherin $\beta 2$ ), the nuclear import receptor of FUS responsible for shuttling FUS through the nuclear pore. Ultimately, this led to decreased nuclear import and accumulation of FUS in the cytoplasm. Additionally, another study found that phosphomimetic substitution at a different site within the NLS, serine 513, exacerbated the cytoplasmic tendency of mutant FUS constructs [112]. The mimetic by itself had no effect on localization, but presumably was affecting transportin-1 binding when coupled with a disease-associated NLS mutation. Though these results were done using an artificial construct, S513 was found to hold consensus for several kinases, indicating its potential to affect FUS in vivo [112].

Disruption of the NLS through mutations or PTMs can cause a shift from nuclear to cytoplasmic localization, which promotes the conditions for FUS to pathologically aggregate. If these changes in localization persist, the PTMs may also change as a consequence making it difficult to know cause-effect relationships. Where in the cell modification occurs may be important; phosphorylation of FUS within cytoplasmic RNP bodies may have different consequences than phosphorylation of FUS at sites of DNA damage. Phosphorylation's connection to disease may also involve molecular mediators, such as transportin-1 or nuclear export machinery. 


\subsection{FUS Methylation}

Methylation of lysines and arginines is a common protein modification. It features prominently in the "histone code" - a complex series of modifications that serve as epigenetic regulators of transcription. The RGG domains of FUS contain numerous methylation sites-both theoretical and experimentally identified - which provide potential for very specific and complex regulation of FUS's activities. Arginine methylation is involved in the nucleocytoplasmic shuttling of many proteins [113], and in recent years has been the focus of much FUS research due to its effects on subcellular localization. It should be noted that, unlike arginine, little experimental evidence supports FUS lysine methylation (Table 1).

Arginine sidechains can exist in several methylation states: unmodified, mono-, or dimethylated. Furthermore, dimethylation can be asymmetric (two methyl groups on a single terminal nitrogen) or symmetric (a methyl group on each terminal nitrogen) [114]. Methylation occurs via protein arginine methyltransferases (PRMTs), which transfer a methyl group from a donor molecule (S-adenosylmethionine) to the guanidino sidechain of arginine. PRMTs are divided into two classes: Type I, which refers to mono- and then dimethylate arginine asymmetrically; and Type II, which refers to mono- and then dimethylate arginine symmetrically. FUS has been shown to be mono- and/or dimethylated by at least two Type I enzymes: PRMT1 and PRMT8 [17,115].

Methylation was first reported by Rappsilber and colleagues in efforts to refine proteomic methods for characterizing arginine methylation. These efforts identified 20 sites of asymmetric dimethylation on FUS [51]. A subsequent mass spectrometry study identified additional arginine asymmetric dimethylation sites, which were proposed to influence FUS's transcriptional activation activity [17]. These studies found that mono- and dimethylation occur within the three RGG regions (Figure 1). In following studies, a connection between dimethylation and FUS's subcellular localization was observed, suggesting a link to disease pathogenesis [16,116].

FUS's C-terminal proline-tyrosine NLS lies at the end of the third RGG region where several arginines govern localization (Figure 1). The NLS and flanking RGG region are recognized by transportin-1. Certain stressors, like hyperosmolar stress or heat shock, cause FUS localization to the cytoplasm as a dimethylated species $[16,117]$. However, when arginines adjacent to the NLS are demethylated, FUS nuclear localization is restored [117]. Specifically, when mono- or unmethylated, the binding affinity between FUS and transportin-1 is increased resulting in greater nuclear import. This favors nuclear retention of FUS [118], thus arginine methylation regulates the balance between nuclear and cytoplasmic localization.

Both ALS and FTLD-associated FUS pathology appear to be potentiated by the accumulation of FUS in the cytoplasm of affected neurons. Malfunction in transport machinery or disruption of normal methylation can therefore indirectly favor a pathological state. In the case of FUS where the majority of ALS-associated mutations fall within or near the NLS, alteration of the transportin-1 interaction through mutation or through PTMs can affect the ability of FUS to go to the nucleus $[117,119]$. Case in point, arginine 514 falls within the NLS and is a known site of methylation. For this reason, inhibitors that target PRMTs have been proposed as potential pharmacological agents against FUS-linked disease [120].

Both PRMT1 and PRMT8 co-associate with FUS in cytoplasmic inclusions that contain either wild-type or ALS-associated mutant FUS species [115]. When inclusions are present, a decrease in nuclear PRMT1 concentration occurs, which disrupts normal nuclear functions, including gene repression through histone methylation [121]. Depletion of PRMT1 from the nucleus likely plays a role in the gain-of-function toxicity associated with FUS inclusions. FTLD-FUS and ALS-FUS have different methylation patterns in their disease states [118]. FTLD-FUS cytoplasmic inclusions are primarily mono-methylated and are found to be associated with transportin-1. However, ALS-FUS is dimethylated in inclusions blocking transportin-1 association. This might be due to the presence or absence of FUS mutations in ALS and FTLD, respectively. ALS-causing FUS mutations are frequently 
in the NLS and increase cytoplasmic localization, whereas mutations are not generally considered to cause FTLD-FUS. However, both mutant and wild-type FUS can be methylated by PRMT1 [115].

Methylated FUS can associate into aggregates but is not required for association into stress granules. Because the PrLD and RRM are considered most important for phase separation, it is not clear what the role of arginine methylation is in RNP body formation. An ALS-causing FUS mutation $(495 \mathrm{X})$ can form cytoplasmic stress granules regardless of methylation status [122]. However, there is relatively little data examining the role of methylation on FUS liquid-liquid phase separation or aggregation. Given that other domains in PrLD-containing proteins do impact phase separation, the addition of a large number of methyl groups (or at very specific sites) could impact protein self-associations. For example, symmetric dimethylation of the RGG domain in the P-body protein Lsm4 promotes RNP body formation [123]. Interestingly, the pKa of arginine side chains is nearly unchanged after any type of methylation [124]. This suggests that any possible impact of methylation on protein self-association would be due to changes in hydrophobicity or hydrogen-bonding character, not simply bulk changes in electrostatic character.

\subsection{FUS Ubiquitination and Cleavage}

Ubiquitination is used for marking proteins for proteasomal degradation, so it is not surprising that pathological inclusions are frequently ubiquitin-positive. Early neuropathological work with tissue samples from ALS and FTD patients demonstrated the presence of TDP-43-negative, ubiquitin-positive subcellular inclusions in some patient samples [125]. The subtype was called aFTLD-U (atypical frontotemporal lobar degeneration with ubiquitin-positive inclusions). FUS was subsequently identified in these bodies [4] and FUS-positive inclusions have been observed as ubiquitin-positive by several groups [4,126-129]. These studies show general colocalization of FUS and ubiquitin to these subcellular inclusions, without precisely showing that FUS itself is ubiquitinated in diseased tissue. Because these inclusions are heterogeneous [126], co-localization of ubiquitin and FUS is not sufficient to establish FUS ubiquitination. Early work on FUS suggested that ubiquitination is not a major post-translational modification, but FUS catabolism is regulated by alternative modifications, chiefly phosphorylation [52].

Analysis of FUS in silico, however, does reveal multiple putative ubiquitination sites toward its C-terminus [130]. Additionally, recent work in a motor neuron-like cell model demonstrates that ubiquitination of FUS-positive inclusions temporally follows the formation of early inclusions, consistent with an overall scheme wherein ubiquitin-mediated autophagy regulates clearance of inclusions [126]. Most convincingly, multiple proteomic analyses demonstrate that ubiquitination is detectable in FUS via mass spectrometry, predominately clustered in the RRM domain (Table 1). Extensive polyubiquitination may not be necessary for turnover since the disordered and low-complexity sequences adjacent to the RRM domain could facilitate proteasomal degradation. Overall the data suggest that direct FUS ubiquitination is likely an important PTM. However, the data remain insufficient to definitively establish the precise extent or significance of ubiquitination, especially in relationship to ALS and FTD.

While direct FUS ubiquitination and its role remains unclear [131], other aggregation-prone proteins associated with intracellular inclusions, including TDP-43 [132], are known to be ubiquitinated with important metabolic consequences. Accumulation of cleaved, C-terminal TDP- 43 fragments is also observed in pathological inclusions; such accumulation of cleavage products in diseased motor neurons has not been reported for FUS [131-135]. In mass spectrometry studies, FUS N-terminal methionine cleavage and acetylation has been observed in human cell models (Table 1). It remains to be answered how and if cleavage of FUS has any role in pathological aggregation or normal function.

\section{Future Research into FUS Post-Translational Modification}

We have only scratched the surface in understanding the relationship between PTMs and FUS activity and self-association. Experimental evidence suggests that at least 22 different arginines in 
FUS's RGG domains can be mono- or dimethylated. Likewise, as many as 32 serines and threonines can be phosphorylated in just the PrLD, not including the additional phosphorylation that occurs in other domains. Therefore, just the PTMs that are experimentally corroborated (not including in silico-predicted sites) suggest that FUS's biochemical character has a high degree of variability in cells. FUS has numerous functional roles both in and outside of the nucleus, so diverse PTM profiles may support complex specific interactions and functions.

Based on the diverse repertoire of PTMs known to occur, it is likely that additional modifications of FUS have yet to be characterized. The types of PTMs observed with histones, such as arginine deimination and lysine methylation, suggest that additional modifications may occur to FUS. The 20 tyrosines in the repeat motifs of the PrLD are especially prime candidates for modification considering their importance in transcriptional activation and phase separation [110,136]. Identification of tyrosine phosphorylation may be lagging due to technical challenges with these PTMs [137].

Of particular interest is relating different FUS PTMs to different activities and propensity to form solid aggregates. FUS can be recruited into different RNP granules with different functions, but the nuances of how PTMs dictate FUS's specific inclusion into any given phase-separated structure remains unknown. Additionally, the PTM profile may change depending on subcellular localization or the type of RNP granule to which FUS is recruited. Ultimately, in relationship to disease, the PTMs that are most likely to increase and decrease solid aggregate formation require greater elucidation. Numerous putative PTM sites overlap with sites of disease-associated mutations which could indicate their relevance to disease. However, because we do not know the complete mechanism of how FUS pathology develops, it is a challenge to determine the effects of PTMs. Their precise roles in complex pathological pathways makes it challenging to predict consequences on disease and disentangle cause and effect relationships. To this end, the proximal signals and mechanisms that lead to FUS modification will need to be determined. For example, how DNA damage is relayed to kinases that phosphorylate FUS is unknown. Similarly, the processes that govern FUS methylation through PRMTs require further study.

Acknowledgments: This work is supported by the National Institute of General Medical Sciences (NIGMS) of the National Institutes of Health (NIH) under Award Numbers R35GM119790 and R01GM118530 (Principal Investigator-Nick Fawzi).

Author Contributions: Shannon N. Rhoads, Zachary T. Monahan, Debra S. Yee and Frank P. Shewmaker wrote the paper.

Conflicts of Interest: The authors declare no conflict of interest. The funding sponsors had no role in the writing of the manuscript.

$\begin{array}{ll}\text { Abbreviations } \\ \text { ALS } & \text { Amyotrophic lateral sclerosis } \\ \text { FTD } & \text { Frontotemporal dementia } \\ \text { FTLD } & \text { Frontotemperal lobar degeneration } \\ \text { FUS } & \text { Fused in sarcoma } \\ \text { LLPS } & \text { Liquid-liquid phase separation } \\ \text { PrLD } & \text { Prion-like domain } \\ \text { PTM } & \text { Post-translational modification } \\ \text { RRM } & \text { RNA recognition motif }\end{array}$

\section{References}

1. Pérez-Losada, J.; Pintado, B.; Gutiérrez-Adán, A.; Flores, T.; Bañares-González, B.; Del Campo, J.C.; Martín-Martín, J.F.; Battaner, E.; Sánchez-García, I. The chimeric FUS/TLS-CHOP fusion protein specifically induces liposarcomas in transgenic mice. Oncogene 2000, 19, 2413-2422. [CrossRef] [PubMed] 
2. Kwiatkowski, T.J., Jr.; Bosco, D.A.; Leclerc, A.L.; Tamrazian, E.; Vanderburg, C.R.; Russ, C.; Davis, A.; Gilchrist, J.; Kasarskis, E.J.; Munsat, T.; et al. Mutations in the FUS/TLS gene on chromosome 16 cause familial amyotrophic lateral sclerosis. Science 2009, 323, 1205-1208. [CrossRef] [PubMed]

3. Vance, C.; Rogelj, B.; Hortobagyi, T.; De Vos, K.J.; Nishimura, A.L.; Sreedharan, J.; Hu, X.; Smith, B.; Ruddy, D.; Wright, P.; et al. Mutations in FUS, an RNA processing protein, cause familial amyotrophic lateral sclerosis type 6. Science 2009, 323, 1208-1211. [CrossRef] [PubMed]

4. Neumann, M.; Rademakers, R.; Roeber, S.; Baker, M.; Kretzschmar, H.A.; Mackenzie, I.R. A new subtype of frontotemporal lobar degeneration with FUS pathology. Brain 2009, 132, 2922-2931. [CrossRef] [PubMed]

5. Sharma, A.; Lyashchenko, A.K.; Lu, L.; Nasrabady, S.E.; Elmaleh, M.; Mendelsohn, M.; Nemes, A.; Tapia, J.C.; Mentis, G.Z.; Shneider, N.A. ALS-associated mutant FUS induces selective motor neuron degeneration through toxic gain of function. Nat. Commun. 2016, 7, 10465. [CrossRef] [PubMed]

6. Armstrong, R.A. Neuronal cytoplasmic inclusions in tau, TDP-43, and FUS molecular subtypes of frontotemporal lobar degeneration share similar spatial patterns. Folia Neuropathol. 2017, 55, 185-192. [CrossRef] [PubMed]

7. Kino, Y.; Washizu, C.; Kurosawa, M.; Yamada, M.; Miyazaki, H.; Akagi, T.; Hashikawa, T.; Doi, H.; Takumi, T.; Hicks, G.G.; et al. FUS/TLS deficiency causes behavioral and pathological abnormalities distinct from amyotrophic lateral sclerosis. Acta Neuropathol. Commun. 2015, 3, 24. [CrossRef] [PubMed]

8. Sama, R.R.; Ward, C.L.; Bosco, D.A. Functions of FUS/TLS from DNA repair to stress response: Implications for ALS. ASN Neuro 2014, 6. [CrossRef] [PubMed]

9. Kuroda, M.; Sok, J.; Webb, L.; Baechtold, H.; Urano, F.; Yin, Y.; Chung, P.; de Rooij, D.G.; Akhmedov, A.; Ashley, T.; et al. Male sterility and enhanced radiation sensitivity in TLS(-/-) mice. EMBO J. 2000, 19, 453-462. [CrossRef] [PubMed]

10. Hicks, G.G.; Singh, N.; Nashabi, A.; Mai, S.; Bozek, G.; Klewes, L.; Arapovic, D.; White, E.K.; Koury, M.J.; Oltz, E.M.; et al. FUS deficiency in mice results in defective b-lymphocyte development and activation, high levels of chromosomal instability and perinatal death. Nat. Genet. 2000, 24, 175-179. [CrossRef] [PubMed]

11. Yu, Y.; Reed, R. FUS functions in coupling transcription to splicing by mediating an interaction between RNAP II and U1 snRNP. Proc. Natl. Acad. Sci. USA 2015, 112, 8608-8613. [CrossRef] [PubMed]

12. Burke, K.A.; Janke, A.M.; Rhine, C.L.; Fawzi, N.L. Residue-by-residue view of in vitro FUS granules that bind the C-terminal domain of RNA polymerase II. Mol. Cell 2015, 60, 231-241. [CrossRef] [PubMed]

13. Yasuda, K.; Zhang, H.; Loiselle, D.; Haystead, T.; Macara, I.G.; Mili, S. The RNA-binding protein FUS directs translation of localized mRNAs in APC-RNP granules. J. Cell Biol. 2013, 203, 737-746. [CrossRef] [PubMed]

14. Zinszner, H.; Sok, J.; Immanuel, D.; Yin, Y.; Ron, D. TLS (FUS) binds RNA in vivo and engages in nucleo-cytoplasmic shuttling. J. Cell Sci. 1997, 110 Pt 15, 1741-1750. [PubMed]

15. Mastrocola, A.S.; Kim, S.H.; Trinh, A.T.; Rodenkirch, L.A.; Tibbetts, R.S. The RNA-binding protein fused in sarcoma (FUS) functions downstream of poly(ADP-ribose) polymerase (PARP) in response to DNA damage. J. Biol. Chem. 2013, 288, 24731-24741. [CrossRef] [PubMed]

16. Sama, R.R.; Ward, C.L.; Kaushansky, L.J.; Lemay, N.; Ishigaki, S.; Urano, F.; Bosco, D.A. FUS/TLS assembles into stress granules and is a prosurvival factor during hyperosmolar stress. J. Cell. Physiol. 2013, 228, 2222-2231. [CrossRef] [PubMed]

17. Du, K.; Arai, S.; Kawamura, T.; Matsushita, A.; Kurokawa, R. TLS and PRMT1 synergistically coactivate transcription at the survivin promoter through TLS arginine methylation. Biochem. Biophys. Res. Commun. 2011, 404, 991-996. [CrossRef] [PubMed]

18. Deng, Q.; Holler, C.J.; Taylor, G.; Hudson, K.F.; Watkins, W.; Gearing, M.; Ito, D.; Murray, M.E.; Dickson, D.W.; Seyfried, N.T.; et al. FUS is phosphorylated by DNA-PK and accumulates in the cytoplasm after DNA damage. J. Neurosci. 2014, 34, 7802-7813. [CrossRef] [PubMed]

19. Wang, W.Y.; Pan, L.; Su, S.C.; Quinn, E.J.; Sasaki, M.; Jimenez, J.C.; Mackenzie, I.R.; Huang, E.J.; Tsai, L.H. Interaction of FUS and HDAC1 regulates DNA damage response and repair in neurons. Nat. Neurosci. 2013, 16, 1383-1391. [CrossRef] [PubMed]

20. Reber, S.; Stettler, J.; Filosa, G.; Colombo, M.; Jutzi, D.; Lenzken, S.C.; Schweingruber, C.; Bruggmann, R.; Bachi, A.; Barabino, S.M.; et al. Minor intron splicing is regulated by FUS and affected by ALS-associated FUS mutants. EMBO J. 2016, 35, 1504-1521. [CrossRef] [PubMed] 
21. Rulten, S.L.; Rotheray, A.; Green, R.L.; Grundy, G.J.; Moore, D.A.; Gomez-Herreros, F.; Hafezparast, M.; Caldecott, K.W. PARP-1 dependent recruitment of the amyotrophic lateral sclerosis-associated protein FUS/TLS to sites of oxidative DNA damage. Nucleic Acids Res. 2014, 42, 307-314. [CrossRef] [PubMed]

22. Naumann, M.; Pal, A.; Goswami, A.; Lojewski, X.; Japtok, J.; Vehlow, A.; Naujock, M.; Günther, R.; Jin, M.; Stanslowsky, N.; et al. Impaired DNA damage response signaling by FUS-NLS mutations leads to neurodegeneration and FUS aggregate formation. Nat. Commun. 2018, 9, 335. [CrossRef] [PubMed]

23. Gardiner, M.; Toth, R.; Vandermoere, F.; Morrice, N.A.; Rouse, J. Identification and characterization of FUS/TLS as a new target of ATM. Biochem. J. 2008, 415, 297-307. [CrossRef] [PubMed]

24. Qiu, H.; Lee, S.; Shang, Y.; Wang, W.Y.; Au, K.F.; Kamiya, S.; Barmada, S.J.; Finkbeiner, S.; Lui, H.; Carlton, C.E.; et al. ALS-associated mutation FUS-R521C causes DNA damage and RNA splicing defects. J. Clin. Investig. 2014, 124, 981-999. [CrossRef] [PubMed]

25. Tan, A.Y.; Riley, T.R.; Coady, T.; Bussemaker, H.J.; Manley, J.L. TLS/FUS (translocated in liposarcoma/fused in sarcoma) regulates target gene transcription via single-stranded DNA response elements. Proc. Natl. Acad. Sci. USA 2012, 109, 6030-6035. [CrossRef] [PubMed]

26. Kim, S.H.; Shanware, N.P.; Bowler, M.J.; Tibbetts, R.S. Amyotrophic lateral sclerosis-associated proteins TDP-43 and FUS/TLS function in a common biochemical complex to co-regulate HDAC6 mRNA. J. Biol. Chem. 2010, 285, 34097-34105. [CrossRef] [PubMed]

27. Yoshimura, A.; Fujii, R.; Watanabe, Y.; Okabe, S.; Fukui, K.; Takumi, T. Myosin-Va facilitates the accumulation of mRNA/protein complex in dendritic spines. Curr. Biol. 2006, 16, 2345-2351. [CrossRef] [PubMed]

28. Kanai, Y.; Dohmae, N.; Hirokawa, N. Kinesin transports RNA: Isolation and characterization of an RNA-transporting granule. Neuron 2004, 43, 513-525. [CrossRef] [PubMed]

29. Schwartz, J.C.; Podell, E.R.; Han, S.S.; Berry, J.D.; Eggan, K.C.; Cech, T.R. FUS is sequestered in nuclear aggregates in ALS patient fibroblasts. Mol. Biol. Cell 2014, 25, 2571-2578. [CrossRef] [PubMed]

30. Coady, T.H.; Manley, J.L. ALS mutations in TLS/FUS disrupt target gene expression. Genes Dev. 2015, 29, 1696-1706. [CrossRef] [PubMed]

31. Groen, E.J.; Fumoto, K.; Blokhuis, A.M.; Engelen-Lee, J.; Zhou, Y.; van den Heuvel, D.M.; Koppers, M.; van Diggelen, F.; van Heest, J.; Demmers, J.A.; et al. ALS-associated mutations in FUS disrupt the axonal distribution and function of SMN. Hum. Mol. Genet. 2013, 22, 3690-3704. [CrossRef] [PubMed]

32. Bentmann, E.; Neumann, M.; Tahirovic, S.; Rodde, R.; Dormann, D.; Haass, C. Requirements for stress granule recruitment of fused in sarcoma (FUS) and TAR DNA-binding protein of $43 \mathrm{kDa}$ (TDP-43). J. Biol. Chem. 2012, 287, 23079-23094. [CrossRef] [PubMed]

33. Rhoads, S.; Monahan, Z.; Yee, D.; Leung, A.; Newcombe, C.; O'Meally, R.; Cole, R.; Shewmaker, F. The prion-like domain of FUS is multiphosphorylated following DNA damage without altering nuclear localization. Submitted.

34. Catherman, A.D.; Durbin, K.R.; Ahlf, D.R.; Early, B.P.; Fellers, R.T.; Tran, J.C.; Thomas, P.M.; Kelleher, N.L. Large-scale top-down proteomics of the human proteome: Membrane proteins, mitochondria, and senescence. Mol. Cell. Proteom. 2013, 12, 3465-3473. [CrossRef] [PubMed]

35. Murray, D.T.; Kato, M.; Lin, Y.; Thurber, K.R.; Hung, I.; McKnight, S.L.; Tycko, R. Structure of FUS protein fibrils and its relevance to self-assembly and phase separation of low-complexity domains. Cell 2017, 171, 615-627. [CrossRef] [PubMed]

36. Monahan, Z.; Ryan, V.H.; Janke, A.M.; Burke, K.A.; Rhoads, S.N.; Zerze, G.H.; O’Meally, R.; Dignon, G.L.; Conicella, A.E.; Zheng, W.; et al. Phosphorylation of the FUS low-complexity domain disrupts phase separation, aggregation, and toxicity. EMBO J. 2017, 36, 2951-2967. [CrossRef] [PubMed]

37. Steentoft, C.; Vakhrushev, S.Y.; Joshi, H.J.; Kong, Y.; Vester-Christensen, M.B.; Schjoldager, K.T.; Lavrsen, K.; Dabelsteen, S.; Pedersen, N.B.; Marcos-Silva, L.; et al. Precision mapping of the human O-GaLNAc glycoproteome through SimpleCell technology. EMBO J. 2013, 32, 1478-1488. [CrossRef] [PubMed]

38. Han, T.W.; Kato, M.; Xie, S.; Wu, L.C.; Mirzaei, H.; Pei, J.; Chen, M.; Xie, Y.; Allen, J.; Xiao, G.; et al. Cell-free formation of RNA granules: Bound RNAs identify features and components of cellular assemblies. Cell 2012, 149, 768-779. [CrossRef] [PubMed]

39. Rigbolt, K.T.; Prokhorova, T.A.; Akimov, V.; Henningsen, J.; Johansen, P.T.; Kratchmarova, I.; Kassem, M.; Mann, M.; Olsen, J.V.; Blagoev, B. System-wide temporal characterization of the proteome and phosphoproteome of human embryonic stem cell differentiation. Sci. Signal. 2011, 4, rs3. [CrossRef] [PubMed] 
40. Geoghegan, V.; Guo, A.; Trudgian, D.; Thomas, B.; Acuto, O. Comprehensive identification of arginine methylation in primary $\mathrm{T}$ cells reveals regulatory roles in cell signalling. Nat. Commun. 2015, 6, 6758. [CrossRef] [PubMed]

41. Larsen, S.C.; Sylvestersen, K.B.; Mund, A.; Lyon, D.; Mullari, M.; Madsen, M.V.; Daniel, J.A.; Jensen, L.J.; Nielsen, M.L. Proteome-wide analysis of arginine monomethylation reveals widespread occurrence in human cells. Sci. Signal. 2016, 9. [CrossRef] [PubMed]

42. Guo, A.; Gu, H.; Zhou, J.; Mulhern, D.; Wang, Y.; Lee, K.A.; Yang, V.; Aguiar, M.; Kornhauser, J.; Jia, X.; et al. Immunoaffinity enrichment and mass spectrometry analysis of protein methylation. Mol. Cell. Proteom. 2014, 13, 372-387. [CrossRef] [PubMed]

43. Hornbeck, P.V.; Zhang, B.; Murray, B.; Kornhauser, J.M.; Latham, V.; Skrzypek, E. Phosphositeplus, 2014 : Mutations, PTMs and recalibrations. Nucleic Acids Res. 2015, 43, D512-D520. [CrossRef] [PubMed]

44. Sylvestersen, K.B.; Horn, H.; Jungmichel, S.; Jensen, L.J.; Nielsen, M.L. Proteomic analysis of arginine methylation sites in human cells reveals dynamic regulation during transcriptional arrest. Mol. Cell. Proteom. 2014, 13, 2072-2088. [CrossRef] [PubMed]

45. Uhlmann, T.; Geoghegan, V.L.; Thomas, B.; Ridlova, G.; Trudgian, D.C.; Acuto, O. A method for large-scale identification of protein arginine methylation. Mol. Cell. Proteom. 2012, 11, 1489-1499. [CrossRef] [PubMed]

46. Bremang, M.; Cuomo, A.; Agresta, A.M.; Stugiewicz, M.; Spadotto, V.; Bonaldi, T. Mass spectrometry-based identification and characterisation of lysine and arginine methylation in the human proteome. Mol. Biosyst. 2013, 9, 2231-2247. [CrossRef] [PubMed]

47. Ong, S.E.; Mittler, G.; Mann, M. Identifying and quantifying in vivo methylation sites by heavy methyl SILAC. Nat. Methods 2004, 1, 119-126. [CrossRef] [PubMed]

48. Fujimoto, K.; Kurokawa, R. Development of a mouse monoclonal antibody for the detection of asymmetric dimethylarginine of translocated in LipoSarcoma/FUsed in sarcoma and its application in analyzing methylated TLS. Cell Biosci. 2014, 4, 77. [CrossRef] [PubMed]

49. Stuart, S.A.; Houel, S.; Lee, T.; Wang, N.; Old, W.M.; Ahn, N.G. A phosphoproteomic comparison of B-RAFV600E and MKK1/2 inhibitors in melanoma cells. Mol. Cell. Proteom. 2015, 14, 1599-1615. [CrossRef] [PubMed]

50. Franz-Wachtel, M.; Eisler, S.A.; Krug, K.; Wahl, S.; Carpy, A.; Nordheim, A.; Pfizenmaier, K.; Hausser, A.; Macek, B. Global detection of protein kinase D-dependent phosphorylation events in nocodazole-treated human cells. Mol. Cell. Proteom. 2012, 11, 160-170. [CrossRef] [PubMed]

51. Rappsilber, J.; Friesen, W.J.; Paushkin, S.; Dreyfuss, G.; Mann, M. Detection of arginine dimethylated peptides by parallel precursor ion scanning mass spectrometry in positive ion mode. Anal. Chem. 2003, 75, 3107-3114. [CrossRef] [PubMed]

52. Perrotti, D.; Iervolino, A.; Cesi, V.; Cirinná, M.; Lombardini, S.; Grassilli, E.; Bonatti, S.; Claudio, P.P.; Calabretta, B. BCR-ABL prevents c-jun-mediated and proteasome-dependent FUS (TLS) proteolysis through a protein kinase cbetaii-dependent pathway. Mol. Cell. Biol. 2000, 20, 6159-6169. [CrossRef] [PubMed]

53. Mertins, P.; Qiao, J.W.; Patel, J.; Udeshi, N.D.; Clauser, K.R.; Mani, D.R.; Burgess, M.W.; Gillette, M.A.; Jaffe, J.D.; Carr, S.A. Integrated proteomic analysis of post-translational modifications by serial enrichment. Nat. Methods 2013, 10, 634-637. [CrossRef] [PubMed]

54. Mertins, P.; Mani, D.R.; Ruggles, K.V.; Gillette, M.A.; Clauser, K.R.; Wang, P.; Wang, X.; Qiao, J.W.; Cao, S.; Petralia, F.; et al. Proteogenomics connects somatic mutations to signalling in breast cancer. Nature 2016, 534, 55-62. [CrossRef] [PubMed]

55. Carrier, M.; Joint, M.; Lutzing, R.; Page, A.; Rochette-Egly, C. Phosphoproteome and transcriptome of RA-responsive and RA-resistant breast cancer cell lines. PLoS ONE 2016, 11, e0157290. [CrossRef] [PubMed]

56. Sharma, K.; D'Souza, R.C.; Tyanova, S.; Schaab, C.; Wiśniewski, J.R.; Cox, J.; Mann, M. Ultradeep human phosphoproteome reveals a distinct regulatory nature of TYR and Ser/THR-based signaling. Cell Rep. 2014, 8, 1583-1594. [CrossRef] [PubMed]

57. Bian, Y.; Song, C.; Cheng, K.; Dong, M.; Wang, F.; Huang, J.; Sun, D.; Wang, L.; Ye, M.; Zou, H. An enzyme assisted RP-RPLC approach for in-depth analysis of human liver phosphoproteome. J. Proteom. 2014, 96, 253-262. [CrossRef] [PubMed]

58. Mayya, V.; Lundgren, D.H.; Hwang, S.I.; Rezaul, K.; Wu, L.; Eng, J.K.; Rodionov, V.; Han, D.K. Quantitative phosphoproteomic analysis of $\mathrm{T}$ cell receptor signaling reveals system-wide modulation of protein-protein interactions. Sci. Signal. 2009, 2. [CrossRef] [PubMed] 
59. Ruse, C.I.; McClatchy, D.B.; Lu, B.; Cociorva, D.; Motoyama, A.; Park, S.K.; Yates, J.R. Motif-specific sampling of phosphoproteomes. J. Proteome Res. 2008, 7, 2140-2150. [CrossRef] [PubMed]

60. Hsu, P.P.; Kang, S.A.; Rameseder, J.; Zhang, Y.; Ottina, K.A.; Lim, D.; Peterson, T.R.; Choi, Y.; Gray, N.S.; Yaffe, M.B.; et al. The mTOR-regulated phosphoproteome reveals a mechanism of mTORC1-mediated inhibition of growth factor signaling. Science 2011, 332, 1317-1322. [CrossRef] [PubMed]

61. Blom, N.; Gammeltoft, S.; Brunak, S. Sequence and structure-based prediction of eukaryotic protein phosphorylation sites. J. Mol. Biol. 1999, 294, 1351-1362. [CrossRef] [PubMed]

62. Amanchy, R.; Periaswamy, B.; Mathivanan, S.; Reddy, R.; Tattikota, S.G.; Pandey, A. A curated compendium of phosphorylation motifs. Nat. Biotechnol. 2007, 25, 285-286. [CrossRef] [PubMed]

63. Povlsen, L.K.; Beli, P.; Wagner, S.A.; Poulsen, S.L.; Sylvestersen, K.B.; Poulsen, J.W.; Nielsen, M.L.; Bekker-Jensen, S.; Mailand, N.; Choudhary, C. Systems-wide analysis of ubiquitylation dynamics reveals a key role for PAF15 ubiquitylation in DNA-damage bypass. Nat. Cell Biol. 2012, 14, 1089-1098. [CrossRef] [PubMed]

64. Kim, W.; Bennett, E.J.; Huttlin, E.L.; Guo, A.; Li, J.; Possemato, A.; Sowa, M.E.; Rad, R.; Rush, J.; Comb, M.J.; et al. Systematic and quantitative assessment of the ubiquitin-modified proteome. Mol. Cell 2011, 44, 325-340. [CrossRef] [PubMed]

65. Wagner, S.A.; Beli, P.; Weinert, B.T.; Nielsen, M.L.; Cox, J.; Mann, M.; Choudhary, C. A proteome-wide, quantitative survey of in vivo ubiquitylation sites reveals widespread regulatory roles. Mol. Cell. Proteom. 2011, 10. [CrossRef] [PubMed]

66. Pan, C.; Olsen, J.V.; Daub, H.; Mann, M. Global effects of kinase inhibitors on signaling networks revealed by quantitative phosphoproteomics. Mol. Cell. Proteom. 2009, 8, 2796-2808. [CrossRef] [PubMed]

67. Tsai, C.F.; Wang, Y.T.; Yen, H.Y.; Tsou, C.C.; Ku, W.C.; Lin, P.Y.; Chen, H.Y.; Nesvizhskii, A.I.; Ishihama, Y.; Chen, Y.J. Large-scale determination of absolute phosphorylation stoichiometries in human cells by motif-targeting quantitative proteomics. Nat. Commun. 2015, 6, 6622. [CrossRef] [PubMed]

68. Kettenbach, A.N.; Schweppe, D.K.; Faherty, B.K.; Pechenick, D.; Pletnev, A.A.; Gerber, S.A. Quantitative phosphoproteomics identifies substrates and functional modules of Aurora and polo-like kinase activities in mitotic cells. Sci. Signal. 2011, 4. [CrossRef] [PubMed]

69. Zhou, H.; Di Palma, S.; Preisinger, C.; Peng, M.; Polat, A.N.; Heck, A.J.; Mohammed, S. Toward a comprehensive characterization of a human cancer cell phosphoproteome. J. Proteome Res. 2013, 12, 260-271. [CrossRef] [PubMed]

70. Olsen, J.B.; Cao, X.J.; Han, B.; Chen, L.H.; Horvath, A.; Richardson, T.I.; Campbell, R.M.; Garcia, B.A.; Nguyen, H. Quantitative profiling of the activity of protein lysine methyltransferase SMYD2 using SILAC-based proteomics. Mol. Cell. Proteom. 2016, 15, 892-905. [CrossRef] [PubMed]

71. Rolland, D.; Basrur, V.; Conlon, K.; Wolfe, T.; Fermin, D.; Nesvizhskii, A.I.; Lim, M.S.; Elenitoba-Johnson, K.S. Global phosphoproteomic profiling reveals distinct signatures in B-cell non-hodgkin lymphomas. Am. J. Pathol. 2014, 184, 1331-1342. [CrossRef] [PubMed]

72. Beli, P.; Lukashchuk, N.; Wagner, S.A.; Weinert, B.T.; Olsen, J.V.; Baskcomb, L.; Mann, M.; Jackson, S.P.; Choudhary, C. Proteomic investigations reveal a role for RNA processing factor THRAP3 in the DNA damage response. Mol. Cell 2012, 46, 212-225. [CrossRef] [PubMed]

73. Wu, F.; Wang, P.; Zhang, J.; Young, L.C.; Lai, R.; Li, L. Studies of phosphoproteomic changes induced by nucleophosmin-anaplastic lymphoma kinase (ALK) highlight deregulation of tumor necrosis factor (TNF)/FAS/TNF-related apoptosis-induced ligand signaling pathway in ALK-positive anaplastic large cell lymphoma. Mol. Cell. Proteom. 2010, 9, 1616-1632. [CrossRef] [PubMed]

74. Palacios-Moreno, J.; Foltz, L.; Guo, A.; Stokes, M.P.; Kuehn, E.D.; George, L.; Comb, M.; Grimes, M.L. Neuroblastoma tyrosine kinase signaling networks involve FYN and LYN in endosomes and lipid rafts. PLoS Comput. Biol. 2015, 11, e1004130. [CrossRef] [PubMed]

75. Jørgensen, C.; Sherman, A.; Chen, G.I.; Pasculescu, A.; Poliakov, A.; Hsiung, M.; Larsen, B.; Wilkinson, D.G.; Linding, R.; Pawson, T. Cell-specific information processing in segregating populations of eph receptor ephrin-expressing cells. Science 2009, 326, 1502-1509. [CrossRef] [PubMed]

76. Darovic, S.; Prpar Mihevc, S.; Župunski, V.; Gunčar, G.; Štalekar, M.; Lee, Y.B.; Shaw, C.E.; Rogelj, B. Phosphorylation of C-terminal tyrosine residue 526 in FUS impairs its nuclear import. J. Cell Sci. 2015, 128, 4151-4159. [CrossRef] [PubMed] 
77. Shin, Y.; Brangwynne, C.P. Liquid phase condensation in cell physiology and disease. Science $2017,357$. [CrossRef] [PubMed]

78. Brangwynne, C.P.; Mitchison, T.J.; Hyman, A.A. Active liquid-like behavior of nucleoli determines their size and shape in Xenopus laevis oocytes. Proc. Natl. Acad. Sci. USA 2011, 108, 4334-4339. [CrossRef] [PubMed]

79. Brangwynne, C.P.; Eckmann, C.R.; Courson, D.S.; Rybarska, A.; Hoege, C.; Gharakhani, J.; Jülicher, F.; Hyman, A.A. Germline P granules are liquid droplets that localize by controlled dissolution/condensation. Science 2009, 324, 1729-1732. [CrossRef] [PubMed]

80. Feric, M.; Vaidya, N.; Harmon, T.S.; Mitrea, D.M.; Zhu, L.; Richardson, T.M.; Kriwacki, R.W.; Pappu, R.V.; Brangwynne, C.P. Coexisting liquid phases underlie nucleolar subcompartments. Cell 2016, 165, 1686-1697. [CrossRef] [PubMed]

81. Kroschwald, S.; Maharana, S.; Mateju, D.; Malinovska, L.; Nüske, E.; Poser, I.; Richter, D.; Alberti, S. Promiscuous interactions and protein disaggregases determine the material state of stress-inducible RNP granules. Elife 2015, 4, e06807. [CrossRef] [PubMed]

82. Molliex, A.; Temirov, J.; Lee, J.; Coughlin, M.; Kanagaraj, A.P.; Kim, H.J.; Mittag, T.; Taylor, J.P. Phase separation by low complexity domains promotes stress granule assembly and drives pathological fibrillization. Cell 2015, 163, 123-133. [CrossRef] [PubMed]

83. Neugebauer, K.M. Special focus on the Cajal body. RNA Biol. 2017, 14, 669-670. [CrossRef] [PubMed]

84. Patel, A.; Lee, H.O.; Jawerth, L.; Maharana, S.; Jahnel, M.; Hein, M.Y.; Stoynov, S.; Mahamid, J.; Saha, S.; Franzmann, T.M.; et al. A liquid-to-solid phase transition of the ALS protein FUS accelerated by disease mutation. Cell 2015, 162, 1066-1077. [CrossRef] [PubMed]

85. Uversky, V.N. Intrinsically disordered proteins in overcrowded milieu: Membrane-less organelles, phase separation, and intrinsic disorder. Curr. Opin. Struct. Biol. 2017, 44, 18-30. [CrossRef] [PubMed]

86. Aumiller, W.M.; Keating, C.D. Phosphorylation-mediated RNA/peptide complex coacervation as a model for intracellular liquid organelles. Nat. Chem. 2016, 8, 129-137. [CrossRef] [PubMed]

87. Schüller, R.; Eick, D. Getting access to low-complexity domain modifications. Trends Biochem. Sci. 2016, 41, 894-897. [CrossRef] [PubMed]

88. Sloutsky, R.; Naegle, K.M. Proteome-level analysis indicates global mechanisms for post-translational regulation of RRM domains. J. Mol. Biol. 2018, 430, 41-44. [CrossRef] [PubMed]

89. Renton, A.E.; Chio, A.; Traynor, B.J. State of play in amyotrophic lateral sclerosis genetics. Nat. Neurosci. 2014, 17, 17-23. [CrossRef] [PubMed]

90. Moore, R.A.; Taubner, L.M.; Priola, S.A. Prion protein misfolding and disease. Curr. Opin. Struct. Biol. 2009, 19, 14-22. [CrossRef] [PubMed]

91. Kryndushkin, D.; Wickner, R.B.; Shewmaker, F. FUS/TLS forms cytoplasmic aggregates, inhibits cell growth and interacts with TDP-43 in a yeast model of amyotrophic lateral sclerosis. Protein Cell 2011, 2, 223-236. [CrossRef] [PubMed]

92. Murakami, T.; Yang, S.P.; Xie, L.; Kawano, T.; Fu, D.; Mukai, A.; Bohm, C.; Chen, F.; Robertson, J.; Suzuki, H.; et al. ALS mutations in FUS cause neuronal dysfunction and death in Caenorhabditis elegans by a dominant gain-of-function mechanism. Hum. Mol. Genet. 2012, 21, 1-9. [CrossRef] [PubMed]

93. Scekic-Zahirovic, J.; Sendscheid, O.; El Oussini, H.; Jambeau, M.; Sun, Y.; Mersmann, S.; Wagner, M.; Dieterlé, S.; Sinniger, J.; Dirrig-Grosch, S.; et al. Toxic gain of function from mutant FUS protein is crucial to trigger cell autonomous motor neuron loss. EMBO J. 2016, 35, 1077-1097. [CrossRef] [PubMed]

94. Nomura, T.; Watanabe, S.; Kaneko, K.; Yamanaka, K.; Nukina, N.; Furukawa, Y. Intranuclear aggregation of mutant FUS/TLS as a molecular pathomechanism of amyotrophic lateral sclerosis. J. Biol. Chem. 2014, 289, 1192-1202. [CrossRef] [PubMed]

95. Wickner, R.B.; Edskes, H.K.; Bateman, D.A.; Kelly, A.C.; Gorkovskiy, A.; Dayani, Y.; Zhou, A. Amyloids and yeast prion biology. Biochemistry 2013, 52, 1514-1527. [CrossRef] [PubMed]

96. Sun, Z.; Diaz, Z.; Fang, X.; Hart, M.P.; Chesi, A.; Shorter, J.; Gitler, A.D. Molecular determinants and genetic modifiers of aggregation and toxicity for the ALS disease protein FUS/TLS. PLoS Biol. 2011, 9, e1000614. [CrossRef] [PubMed]

97. Lin, Y.; Protter, D.S.; Rosen, M.K.; Parker, R. Formation and maturation of phase-separated liquid droplets by RNA-binding proteins. Mol. Cell 2015, 60, 208-219. [CrossRef] [PubMed]

98. Harrison, A.F.; Shorter, J. RNA-binding proteins with prion-like domains in health and disease. Biochem. J. 2017, 474, 1417-1438. [CrossRef] [PubMed] 
99. Murakami, T.; Qamar, S.; Lin, J.Q.; Schierle, G.S.; Rees, E.; Miyashita, A.; Costa, A.R.; Dodd, R.B.; Chan, F.T.; Michel, C.H.; et al. ALS/FTD mutation-induced phase transition of FUS liquid droplets and reversible hydrogels into irreversible hydrogels impairs RNP granule function. Neuron 2015, 88, 678-690. [CrossRef] [PubMed]

100. Bosco, D.A.; Lemay, N.; Ko, H.K.; Zhou, H.; Burke, C.; Kwiatkowski, T.J., Jr.; Sapp, P.; McKenna-Yasek, D.; Brown, R.H., Jr.; Hayward, L.J. Mutant FUS proteins that cause amyotrophic lateral sclerosis incorporate into stress granules. Hum. Mol. Genet. 2010, 19, 4160-4175. [CrossRef] [PubMed]

101. Johnson, G.V.; Stoothoff, W.H. Tau phosphorylation in neuronal cell function and dysfunction. J. Cell Sci. 2004, 117, 5721-5729. [CrossRef] [PubMed]

102. Rodríguez-Martín, T.; Cuchillo-Ibáñez, I.; Noble, W.; Nyenya, F.; Anderton, B.H.; Hanger, D.P. Tau phosphorylation affects its axonal transport and degradation. Neurobiol. Aging 2013, 34, 2146-2157. [CrossRef] [PubMed]

103. Liu, Z.; Li, T.; Li, P.; Wei, N.; Zhao, Z.; Liang, H.; Ji, X.; Chen, W.; Xue, M.; Wei, J. The ambiguous relationship of oxidative stress, tau hyperphosphorylation, and autophagy dysfunction in Alzheimer's disease. Oxid. Med. Cell. Longev. 2015, 2015, 352723. [CrossRef] [PubMed]

104. Tenreiro, S.; Reimão-Pinto, M.M.; Antas, P.; Rino, J.; Wawrzycka, D.; Macedo, D.; Rosado-Ramos, R.; Amen, T.; Waiss, M.; Magalhães, F.; et al. Phosphorylation modulates clearance of alpha-synuclein inclusions in a yeast model of Parkinson's disease. PLoS Genet. 2014, 10, e1004302. [CrossRef] [PubMed]

105. Zhang, S.; Xie, J.; Xia, Y.; Yu, S.; Gu, Z.; Feng, R.; Luo, G.; Wang, D.; Wang, K.; Jiang, M.; et al. LK6/Mnk2a is a new kinase of alpha synuclein phosphorylation mediating neurodegeneration. Sci. Rep. 2015, 5, 12564. [CrossRef] [PubMed]

106. Li, H.Y.; Yeh, P.A.; Chiu, H.C.; Tang, C.Y.; Tu, B.P. Hyperphosphorylation as a defense mechanism to reduce TDP-43 aggregation. PLOS ONE 2011, 6, e23075. [CrossRef] [PubMed]

107. Nonaka, T.; Suzuki, G.; Tanaka, Y.; Kametani, F.; Hirai, S.; Okado, H.; Miyashita, T.; Saitoe, M.; Akiyama, H.; Masai, H.; et al. Phosphorylation of TAR DNA-binding protein of $43 \mathrm{kDa}$ (TDP-43) by truncated casein kinase $1 \delta$ triggers mislocalization and accumulation of TDP-43. J. Biol. Chem. 2016, 291, 5473-5483. [CrossRef] [PubMed]

108. Altmeyer, M.; Neelsen, K.J.; Teloni, F.; Pozdnyakova, I.; Pellegrino, S.; Grøfte, M.; Rask, M.B.; Streicher, W.; Jungmichel, S.; Nielsen, M.L.; et al. Liquid demixing of intrinsically disordered proteins is seeded by poly(ADP-ribose). Nat. Commun. 2015, 6, 8088. [CrossRef] [PubMed]

109. Shelkovnikova, T.A.; Robinson, H.K.; Southcombe, J.A.; Ninkina, N.; Buchman, V.L. Multistep process of FUS aggregation in the cell cytoplasm involves RNA-dependent and RNA-independent mechanisms. Hum. Mol. Genet. 2014, 23, 5211-5226. [CrossRef] [PubMed]

110. Lin, Y.; Currie, S.L.; Rosen, M.K. Intrinsically disordered sequences enable modulation of protein phase separation through distributed tyrosine motifs. J. Biol. Chem. 2017, 292, 19110-19120. [CrossRef] [PubMed]

111. Wang, A.; Conicella, A.E.; Schmidt, H.B.; Martin, E.W.; Rhoads, S.N.; Reeb, A.N.; Nourse, A.; Montero, D.R.; Ryan, V.H.; Rohatgi, R.; et al. A single N-terminal phosphomimic disrupts TDP-43 polymerization, phase separationand RNA splicing. EMBO J. 2018, 37. [CrossRef] [PubMed]

112. Kino, Y.; Washizu, C.; Aquilanti, E.; Okuno, M.; Kurosawa, M.; Yamada, M.; Doi, H.; Nukina, N. Intracellular localization and splicing regulation of FUS/TLS are variably affected by amyotrophic lateral sclerosis-linked mutations. Nucleic Acids Res. 2011, 39, 2781-2798. [CrossRef] [PubMed]

113. Bedford, M.T.; Clarke, S.G. Protein arginine methylation in mammals: Who, what, and why. Mol. Cell 2009, 33, 1-13. [CrossRef] [PubMed]

114. Boriack-Sjodin, P.A.; Swinger, K.K. Protein methyltransferases: A distinct, diverse, and dynamic family of enzymes. Biochemistry 2016, 55, 1557-1569. [CrossRef] [PubMed]

115. Scaramuzzino, C.; Monaghan, J.; Milioto, C.; Lanson, N.A., Jr.; Maltare, A.; Aggarwal, T.; Casci, I.; Fackelmayer, F.O.; Pennuto, M.; Pandey, U.B. Protein arginine methyltransferase 1 and 8 interact with FUS to modify its sub-cellular distribution and toxicity in vitro and in vivo. PLoS ONE 2013, 8, e61576. [CrossRef] [PubMed]

116. Tradewell, M.L.; Yu, Z.; Tibshirani, M.; Boulanger, M.C.; Durham, H.D.; Richard, S. Arginine methylation by PRMT1 regulates nuclear-cytoplasmic localization and toxicity of FUS/TLS harbouring ALS-linked mutations. Hum. Mol. Genet. 2012, 21, 136-149. [CrossRef] [PubMed] 
117. Dormann, D.; Madl, T.; Valori, C.F.; Bentmann, E.; Tahirovic, S.; Abou-Ajram, C.; Kremmer, E.; Ansorge, O.; Mackenzie, I.R.; Neumann, M.; et al. Arginine methylation next to the PY-NLS modulates transportin binding and nuclear import of FUS. EMBO J. 2012, 31, 4258-4275. [CrossRef] [PubMed]

118. Suárez-Calvet, M.; Neumann, M.; Arzberger, T.; Abou-Ajram, C.; Funk, E.; Hartmann, H.; Edbauer, D.; Kremmer, E.; Göbl, C.; Resch, M.; et al. Monomethylated and unmethylated FUS exhibit increased binding to transportin and distinguish FTLD-FUS from ALS-FUS. Acta Neuropathol. 2016, 131, 587-604. [CrossRef] [PubMed]

119. Niu, C.; Zhang, J.; Gao, F.; Yang, L.; Jia, M.; Zhu, H.; Gong, W. FUS-NLS/transportin 1 complex structure provides insights into the nuclear targeting mechanism of FUS and the implications in ALS. PLoS ONE 2012, 7, e47056. [CrossRef] [PubMed]

120. Fujii, S.; Takanashi, K.; Kitajo, K.; Yamaguchi, A. Treatment with a global methyltransferase inhibitor induces the intranuclear aggregation of ALS-linked FUS mutant in vitro. Neurochem. Res. 2016, 41, 826-835. [CrossRef] [PubMed]

121. Tibshirani, M.; Tradewell, M.L.; Mattina, K.R.; Minotti, S.; Yang, W.; Zhou, H.; Strong, M.J.; Hayward, L.J.; Durham, H.D. Cytoplasmic sequestration of FUS/TLS associated with ALS alters histone marks through loss of nuclear protein arginine methyltransferase 1. Hum. Mol. Genet. 2015, 24, 773-786. [CrossRef] [PubMed]

122. Baron, D.M.; Kaushansky, L.J.; Ward, C.L.; Sama, R.R.; Chian, R.J.; Boggio, K.J.; Quaresma, A.J.; Nickerson, J.A.; Bosco, D.A. Amyotrophic lateral sclerosis-linked FUS/TLS alters stress granule assembly and dynamics. Mol. Neurodegener. 2013, 8, 30. [CrossRef] [PubMed]

123. Arribas-Layton, M.; Dennis, J.; Bennett, E.J.; Damgaard, C.K.; Lykke-Andersen, J. The C-terminal RGG domain of human LSM4 promotes processing body formation stimulated by arginine dimethylation. Mol. Cell. Biol. 2016, 36, 2226-2235. [CrossRef] [PubMed]

124. Evich, M.; Stroeva, E.; Zheng, Y.G.; Germann, M.W. Effect of methylation on the side-chain PKA value of arginine. Protein Sci. 2016, 25, 479-486. [CrossRef] [PubMed]

125. Mackenzie, I.R.; Foti, D.; Woulfe, J.; Hurwitz, T.A. Atypical frontotemporal lobar degeneration with ubiquitin-positive, TDP-43-negative neuronal inclusions. Brain 2008, 131, 1282-1293. [CrossRef] [PubMed]

126. Farrawell, N.E.; Lambert-Smith, I.A.; Warraich, S.T.; Blair, I.P.; Saunders, D.N.; Hatters, D.M.; Yerbury, J.J. Distinct partitioning of ALS associated TDP-43, FUS and SOD1 mutants into cellular inclusions. Sci. Rep. 2015, 5, 13416. [CrossRef] [PubMed]

127. Deng, H.X.; Zhai, H.; Bigio, E.H.; Yan, J.; Fecto, F.; Ajroud, K.; Mishra, M.; Ajroud-Driss, S.; Heller, S.; Sufit, R.; et al. FUS-immunoreactive inclusions are a common feature in sporadic and non-SOD1 familial amyotrophic lateral sclerosis. Ann. Neurol. 2010, 67, 739-748. [CrossRef] [PubMed]

128. Seelaar, H.; Klijnsma, K.Y.; De Koning, I.; Van der Lugt, A.; Chiu, W.Z.; Azmani, A.; Rozemuller, A.J.; Van Swieten, J.C. Frequency of ubiquitin and FUS-positive, TDP-43-negative frontotemporal lobar degeneration. J. Neurol. 2010, 257, 747-753. [CrossRef] [PubMed]

129. Dormann, D.; Haass, C. TDP-43 and FUS: A nuclear affair. Trends Neurosci. 2011, 34, 339-348. [CrossRef] [PubMed]

130. Radivojac, P.; Vacic, V.; Haynes, C.; Cocklin, R.R.; Mohan, A.; Heyen, J.W.; Goebl, M.G.; Iakoucheva, L.M. Identification, analysis, and prediction of protein ubiquitination sites. Proteins 2010, 78, 365-380. [CrossRef] [PubMed]

131. Guerrero, E.N.; Wang, H.; Mitra, J.; Hegde, P.M.; Stowell, S.E.; Liachko, N.F.; Kraemer, B.C.; Garruto, R.M.; Rao, K.S.; Hegde, M.L. TDP-43/FUS in motor neuron disease: Complexity and challenges. Prog. Neurobiol. 2016, 145-146, 78-97. [CrossRef] [PubMed]

132. Neumann, M.; Sampathu, D.M.; Kwong, L.K.; Truax, A.C.; Micsenyi, M.C.; Chou, T.T.; Bruce, J.; Schuck, T.; Grossman, M.; Clark, C.M.; et al. Ubiquitinated TDP-43 in frontotemporal lobar degeneration and amyotrophic lateral sclerosis. Science 2006, 314, 130-133. [CrossRef] [PubMed]

133. Zhang, Y.J.; Xu, Y.F.; Cook, C.; Gendron, T.F.; Roettges, P.; Link, C.D.; Lin, W.L.; Tong, J.; Castanedes-Casey, M.; Ash, P.; et al. Aberrant cleavage of TDP-43 enhances aggregation and cellular toxicity. Proc. Natl. Acad. Sci. USA 2009, 106, 7607-7612. [CrossRef] [PubMed]

134. Da Cruz, S.; Cleveland, D.W. Understanding the role of TDP-43 and FUS/TLS in ALS and beyond. Curr. Opin. Neurobiol. 2011, 21, 904-919. [CrossRef] [PubMed]

135. Lagier-Tourenne, C.; Polymenidou, M.; Cleveland, D.W. TDP-43 and FUS/TLS: Emerging roles in RNA processing and neurodegeneration. Hum. Mol. Genet. 2010, 19, R46-R64. [CrossRef] [PubMed] 
136. Kwon, I.; Kato, M.; Xiang, S.; Wu, L.; Theodoropoulos, P.; Mirzaei, H.; Han, T.; Xie, S.; Corden, J.L.; McKnight, S.L. Phosphorylation-regulated binding of RNA polymerase II to fibrous polymers of low-complexity domains. Cell 2013, 155, 1049-1060. [CrossRef] [PubMed]

137. Boersema, P.J.; Foong, L.Y.; Ding, V.M.; Lemeer, S.; van Breukelen, B.; Philp, R.; Boekhorst, J.; Snel, B.; den Hertog, J.; Choo, A.B.; et al. In-depth qualitative and quantitative profiling of tyrosine phosphorylation using a combination of phosphopeptide immunoaffinity purification and stable isotope dimethyl labeling. Mol. Cell. Proteom. 2010, 9, 84-99. [CrossRef] [PubMed]

(C) 2018 by the authors. Licensee MDPI, Basel, Switzerland. This article is an open access article distributed under the terms and conditions of the Creative Commons Attribution (CC BY) license (http:/ / creativecommons.org/licenses/by/4.0/). 